\title{
Annelid assemblages in soft bottoms subjected to human impact in the Urías estuary (Sinaloa, Mexico)
}

\author{
Nuria Méndez * \\ Laboratorio de Invertebrados Bentónicos, Instituto de Ciencias del Mar y Limnología, UNAM, Unidad Académica Mazatlán, \\ Apdo. Postal 811, Mazatlán 82000, Sinaloa, Mexico
}

Received 4 December 2001; received in revised form 27 March 2002; accepted 14 June 2002

\begin{abstract}
The annelid fauna inhabiting soft bottoms was analysed during February and April, 1997 in the Urías estuary which is mostly surrounded by mangrove swamps, but is also subjected to the effect of several anthropogenic activities. Classification and ordination techniques were used to perform the characterisation of the system based on the annelid assemblages according to environmental variables (mainly organic matter content and percentage of mud). Three zones were found: (1) 'very polluted zone', in front of a slaughterhouse and a fish processing factory with a total lack of macrofauna due to the strong enrichment of the sediment in organic matter; (2) 'polluted zones', characterised by the sporadic presence of oligochaetes in front of a domestic sewage effluent, by the dominance of Capitella capitata close to a thermoelectric plant, and by the dominance of Streblospio benedicti and oligochaetes in the surroundings of an upstream shrimp farm; (3) 'unpolluted zones', in the mouth of the estuary and an area surrounded by mangrove trees, with low organic matter content in sediment, high diversity and no dominant species. () 2002 Ifremer/CNRS/IRD/Éditions scientifiques et médicales Elsevier SAS. All rights reserved.
\end{abstract}

\section{Résumé}

La faune d'annélides habitant les sustrats meubles a été analysée en février et en avril 1997 dans l'estuaire d'Urías qui est entièrement ceinturé par une mangrove, mais est également soumis à l'effet de plusieurs activités anthropiques. Des techniques de classification et d'ordination ont été employées pour caractériser le système, basé sur les assemblages d'annélides selon des variables environnementales (contenu en matière organique et pourcentage de vase principalement). Trois zones ont été identifiées : (1) la «zone très polluée », devant un atelier d'abattage et une usine de traitement du poisson, avec un manque total de macrofaune dû à un fort enrichissement du sédiment en matière organique ; (2) les «zones polluées », caractérisées par la présence sporadique d'oligochètes devant un effluent d'égouts domestiques, par la dominance de Capitella capitata près d'une usine thermoélectrique, et par la dominance de Streblospio benedicti et des oligochètes à proximité d'une ferme à crevettes en amont ; (3) la « zone non polluée », dans l'embouchure de l'estuaire et une zone entourée par des arbres de palétuviers, avec une faible teneur en matière organique dans le sédiment, une diversité élevée et aucune dominance d'espèce. (C) 2002 Ifremer/CNRS/IRD/Éditions scientifiques et médicales Elsevier SAS. Tous droits réservés.

Keywords: Annelids; Soft bottoms; Urías estuary; Ecosystem disturbance; Indicator species

Mots clés: Annélides; Fonds meubles; L’estuaire d’Urías; Écosystème perturbé; Espèces indicatrices

\section{Introduction}

Human activities produce environmental disturbances of chemical and/or physical origin that affect shallow-water benthic marine communities. The most universal pollutant

\footnotetext{
* Corresponding author.

E-mail address: nuri@ola.icmyl.unam.mx (N. Méndez).
}

in the sea, in highly polluted areas, is organic matter coming from sewage outfalls, which produces an organic enrichment of sediments. This may induce changes in the number of species, abundance and biomass of benthic communities (Pearson and Rosenberg, 1978; Hily, 1983; Warwick et al., 1987; Méndez et al., 1998).

Sediments and specially benthic fauna or bottom dwelling organisms in general are good indicators of organic 
pollution, as they have a 'memory' (chemical in the first case, ecological in the second) of both past and present disturbances. Polychaetes have been found to be indicators of organic pollution, due to their high abundance and sensitivity to different amounts of organic matter in sediments. Studies performed by Reish (1959), Bellan (1967a, b), Glémarec and Hily (1981), Hily (1983), Hily and Glémarec (1990), Levin et al. (1996), Borja et al. (2000) and Inglis and Kross (2000), among others, have demonstrated that some families of polychaetes such as Capitellidae, Spionidae and Cirratulidae are excellent indicators of different degrees of organic pollution produced mainly by domestic sewage. Warwick and Clarke (1993) have also mentioned the importance of oligochaetes in stressed environments. Capitella capitata has been considered as a universal pollution indicator since it proliferates in sediments containing high amounts of organic matter (Reish, 1959; Bellan, 1967a, b; Grassle and Grassle, 1974; Pearson and Rosenberg, 1978; Kikuchi, 1979; Bellan, 1984; Tsutsumi et al., 1990). So, the spatial distribution of polychaetes along an enrichment gradient may reflect different degrees of disturbance, which allows the description of different biotopes subjected to varying degrees of pollution (Reish, 1959; Bellan, 1967a, b).

The Urías estuary is a coastal lagoon permanently connected to the sea by a wide mouth. It is subjected to the effect of several anthropogenic activities, which cause eutrophication, by nutrients and organic matter in the sediment (Ochoa-Izaguirre et al., 2002). Thus, this estuary is a suitable ecosystem to observe organic pollution impact through the study of benthic organisms.

Although several studies have been performed in the coast near Mazatlán, few biological studies correspond specifically to the Urías estuary. Benthic flora and fauna associated with soft bottoms have been studied by AlvarezLeón (1980), and Ochoa-Izaguirre et al. (2002). Up to now, only 13 polychaete species belonging to three genera have been reported from soft bottoms of the Urías estuary by Alvarez-León (1980). Thus, this study was designed to contribute to the knowledge of polychaetes inhabiting soft bottoms from the estuary. Moreover, a characterisation of the system by means of the spatial analysis of annelids associated with sediments affected by anthropogenic activities is presented here.

\section{Materials and methods}

\subsection{Study area}

The Urías estuary is located in the state of Sinaloa along the southeast coast of the Gulf of California between $23^{\circ} 10^{\prime} 36^{\prime \prime}$ and $23^{\circ} 13^{\prime} 00^{\prime \prime} \mathrm{N}$ and $106^{\circ} 20^{\prime} 00^{\prime \prime}$ and $106^{\circ} 25^{\prime} 35^{\prime \prime} \mathrm{W}$, near the city of Mazatlán. It has a surface area of $18 \mathrm{~km}^{2}$ and a length of $17 \mathrm{~km}$. The climate is tropical/sub-tropical, with two contrasting seasons. This water body has been considered as an estuarine system during the rainy season (July-October) and antiestuarine system in the drought season (November-June) (OchoaIzaguirre et al., 2002). The average annual temperature is $25^{\circ} \mathrm{C}$, with a monthly average temperature ranging from $19.7^{\circ} \mathrm{C}$ in February to $28.0^{\circ} \mathrm{C}$ in August (Soto-Jiménez and Páez-Osuna, 2001). The average annual rainfall is $800 \mathrm{~mm}$ (occurring mainly during the rainy season). The average annual salinity is 34 Alvarez-León (1980). Ochoa-Izaguirre et al. (2002) calculated an average salinity during the drought season of 39.4 (maximum 45.5) and 31.7 during the rains (minimum 9.0). Several anthropogenic activities occur in the Urías estuary. The Mazatlán Harbour and fishing fleet are located along the first $3 \mathrm{~km}$ from the mouth. Between the 3rd and 7th $\mathrm{km}$ from the mouth, several activities occur: domestic seawage (the 'Infiernillo' stream), a fish processing factory, a slaughterhouse and a thermoelectric plant. The remaining length of the estuary is lined by mangrove trees and the upper part receives the shrimp pond effluents coming from the 'Clementina' shrimp farm (OchoaIzaguirre et al., 2002). Ten stations located close to the different anthropogenic effluents and mangroves were sampled along the estuary in order to detect possible influences from these pollution sources (Fig. 1).

\subsection{Sampling and laboratory work}

Sampling was performed on February and April 1997, during the drought season. Samples of sediment were taken with a $26.5 \times 12.5 \mathrm{~cm}$ van Veen grab. The material contained in one grab was sieved through a $0.5 \mathrm{~mm}$ mesh to collect the annelid fauna. According to conventional techniques, the retained material was fixed with $4 \%$ formaldehyde. Animals were sorted and preserved in $70 \%$ alcohol. Polychaetes were identified according to Hartman (1968; 1969), Fauchald (1977), Kudenov (1980) and (HernándezAlcántara, 1992).

Additional samples of sediment were collected at each station to analyse grain size and organic matter content. Percentages of organic matter were obtained by loss of ignition (Dean, 1974). According to conventional methods, samples of about $200 \mathrm{~g}$ were sieved through a $2 \mathrm{~mm}$ mesh to separate gravel from sand and a $0.0625 \mathrm{~mm}$ mesh to separate sand from mud (the later considered as a mixture of silt and clay). Grain size was expressed as percentage of mud.

\subsection{Data analyses}

Shannon diversity and Rarefaction curves (Sanders, 1968) were calculated with the Biodiversity Professional, 1997 program. The similarities among stations were established by the Bray-Curtis cluster analysis (Group average link), using the abundance of species transformed to fourth root (Primer $5 \beta$ for Windows; version 5.04, 2000). 


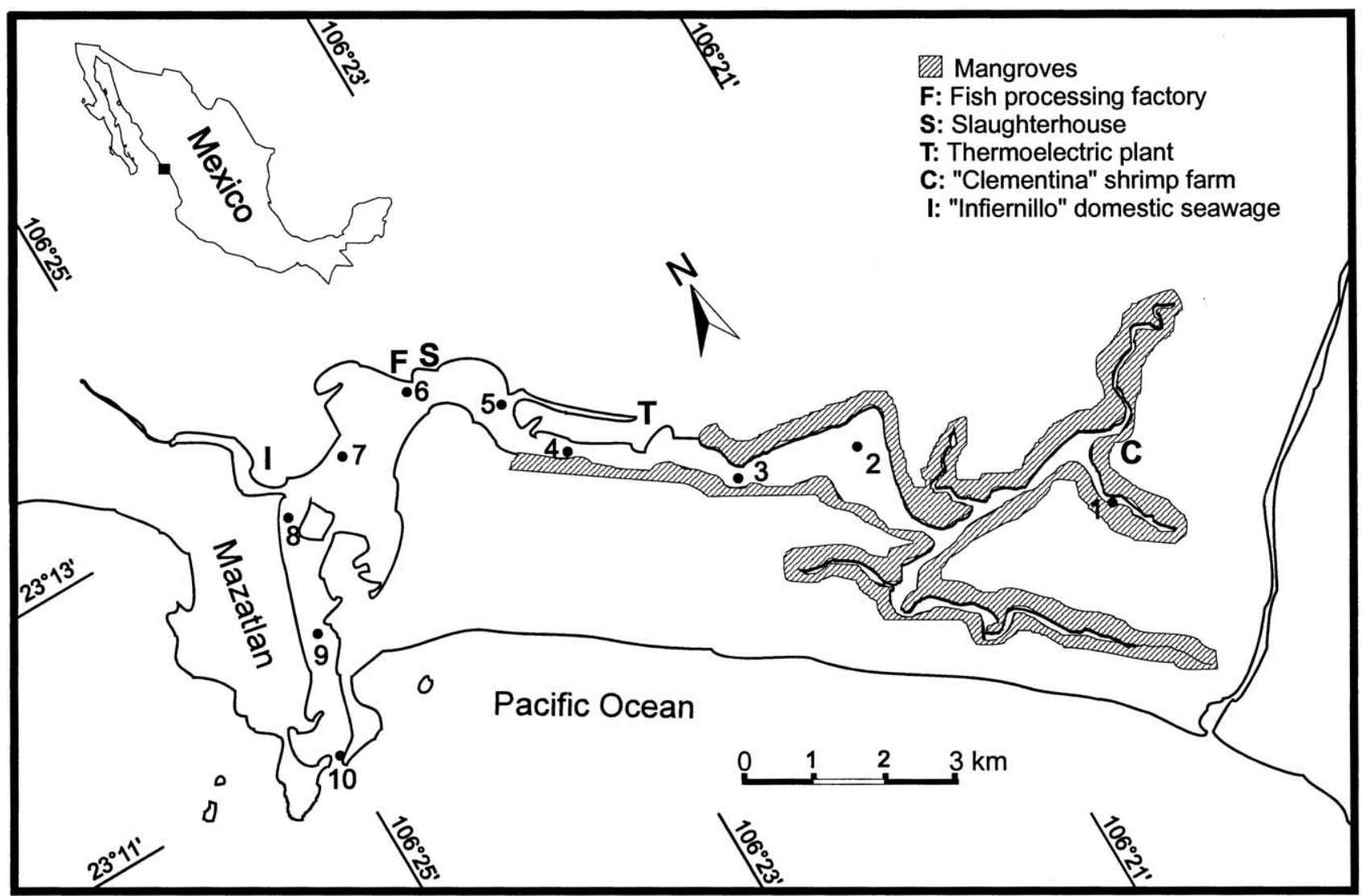

Fig. 1. Study area showing the collection stations.

Pearson's correlations were calculated between biotic (abundance, species number and diversity) and abiotic (organic matter, percentage of mud and depth) variables. In order to know the possible factors influencing the annelid assemblages, a canonical correspondence analysis was performed (Pcord program, ver. 2.05, 1995) taking into account the abundance of the dominant and frequent species as biotic variables and the above mentioned abiotic variables. Dominance was calculated as Dm $=\left(n_{i} / N\right) \times 100$, where Dm is the mean dominance index for species $i ; n_{i}$, the number of individuals belonging to species $i$; , the total number of individuals belonging to all the species (Picard, 1965). According to Glémarec (1964), frequency was calculated as $F=\left(m_{i} \times 100\right) / M$, where $m_{i}$ is the number of samples in which species $i$ appeared and $M$, the total number of samples.

\section{Results}

A total of 5943 individuals representing 75 species were collected during the study, from which 2168 individuals belonging to 61 species were sampled in February and 3775 individuals representing 52 species in April (Table 1). Some specimens from the families Maldanidae, Polynoidae, Polyodontidae, Nereidae, Goniadidae, Dorvilleidae, Terebellidae and Sabellidae could not be identified because they appeared broken in the samples. Polydora sp. and Tharyx sp. were identified only to genus level due to the lack of some important taxonomic structures. Due to the difficulty in identification, Oligochaetes were only identified to class level and considered as a single taxon on the analyses.

Taking into account the 75 studied species, results derived from cluster analyses, rarefaction curves and Shannon diversity values during the two studied months showed clear assemblages (Fig. 2; Table 2). Three groups of stations can be distinguished: (1) stations 1, 5, 6 and 8 influenced by anthropogenic activities, with low diversity values ranging from 0 to 1.5 and characterised by a low number of individuals (in some cases, total absence; Fig. 2c, d; Table 2) and few species. Percentage of mud vary from 45.5 to $80.6 \%$ and organic matter content from 5.13 to $10.95 \%$ (Table 2); (2) stations surrounded by mangrove trees (stations 2,3 and 4), with diversity ranging from 1.6 to 2.7 , percentage of mud from 13.8 to $70.9 \%$ and organic matter content from 4.7 to $8.2 \%$ (Fig. 2; Table 2); (3) stations located close to the mouth of the estuary $(7,9,10)$, with high diversity values (2.6-4.5) and represented by high abundance and species numbers (Fig. 2c, d; Table 2). Percentage of mud varies from 6.11 to $29.17 \%$ and organic matter from 1.6 to $5.6 \%$ (Table 2).

The Pearson's correlation index showed significant correlation between mud and organic matter and both abiotic 
Table 1

Absolute abundance of annelids in the collection sites over the study.








a
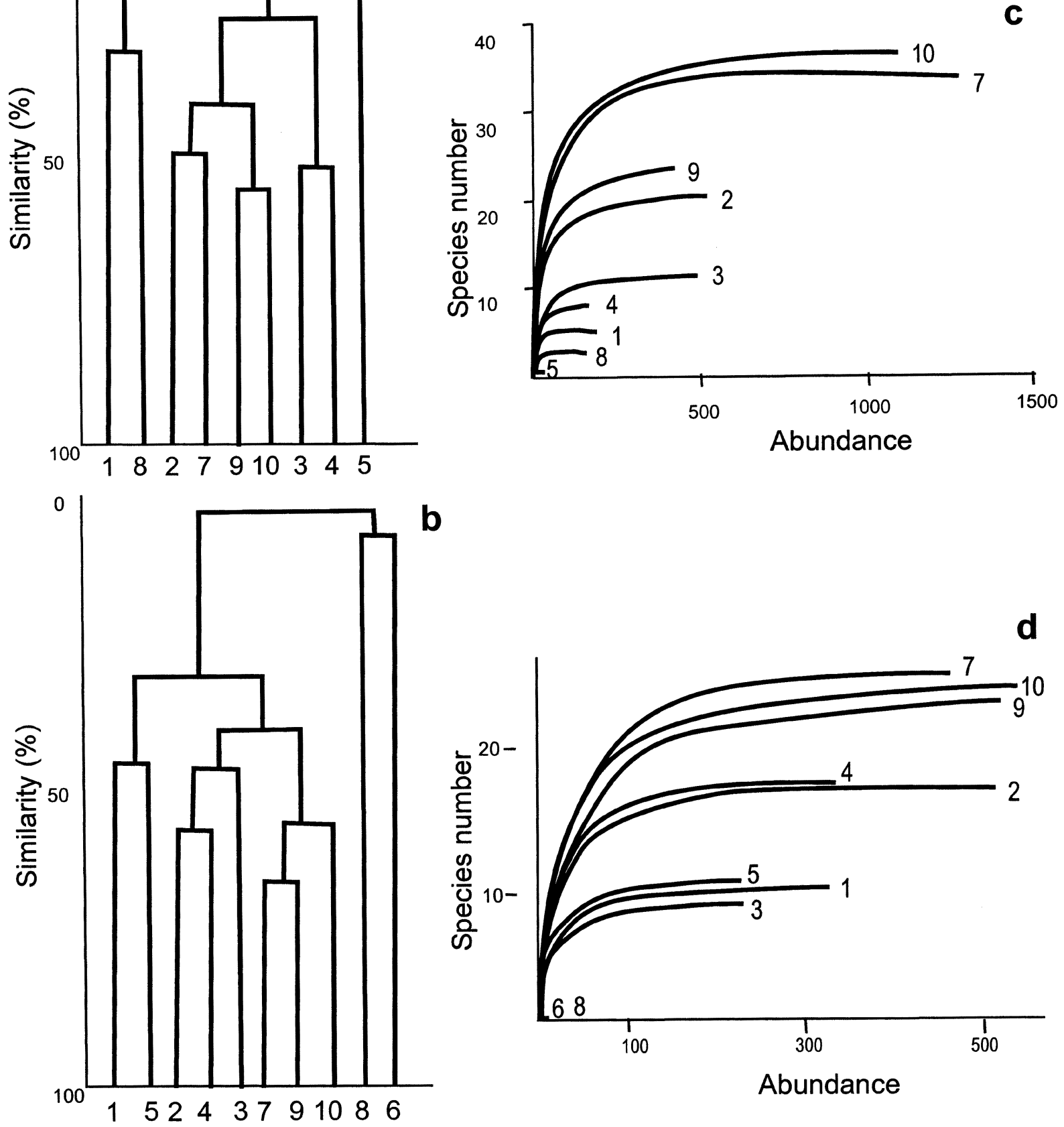

b



Fig. 2. Dendrograms (Bray-Curtis cluster analyses) showing the grouping of stations: (a) February, 1997; (b) April 1997; Sanders Rarefaction plots (c) February, 1997; (d) April 1997.

variables with the three biotic variables. Depth resulted positively correlated with the biotic variables, especially with abundance. The correlation among the studied biotic variables resulted significant and positive (Table 3 ).

In order to have a closer approach of the species distribution according to the environmental variables, the characteristic species of the system were determined based on their dominance and frequency over the study. The 22 dominant and frequent species are listed in the legend for Fig. 3. The spatial distribution of species and stations according to the biotic variables is represented in Fig. 3. A total of $17.4 \%$ of the variance was explained by the first axis and $16.5 \%$ by the second axis. Granulometry and organic matter content in sediments resulted the most important 
Table 2

Biotic and abiotic variables over the study

\begin{tabular}{|c|c|c|c|c|c|c|}
\hline Collection stations & Absolute abundance & Species number & Shannon diversity & $\%$ mud & $\%$ organic matter & Depth (m) \\
\hline \multicolumn{7}{|l|}{ February, 1997} \\
\hline 1 & 253 & 6 & 1.06 & 80.66 & 9.47 & 1.75 \\
\hline 2 & 219 & 24 & 2.874 & 29.17 & 5.56 & 1.2 \\
\hline 3 & 88 & 15 & 2.757 & 70.97 & 8.21 & 2.5 \\
\hline 4 & 90 & 13 & 2.252 & 42.25 & 5.45 & 3.3 \\
\hline 5 & 2 & 2 & 1 & 58.19 & 8.33 & 1.1 \\
\hline 6 & 0 & 0 & 0 & 93.42 & 11.50 & 5.5 \\
\hline 7 & 705 & 36 & 3.167 & 15.48 & 3.09 & 9 \\
\hline 8 & 35 & 3 & 0.373 & 97.89 & 10.95 & 6.1 \\
\hline 9 & 202 & 25 & 3.017 & 6.11 & 1.62 & 5.5 \\
\hline 10 & 574 & 38 & 4.266 & 25.06 & 3.68 & 11.5 \\
\hline \multicolumn{7}{|l|}{ April, 1997} \\
\hline 1 & 420 & 11 & 1.625 & 50.84 & 5.13 & 1.8 \\
\hline 2 & 272 & 19 & 3.201 & 13.79 & 4.66 & 1 \\
\hline 3 & 77 & 11 & 2.329 & 10.26 & 3.67 & 2.5 \\
\hline 4 & 358 & 20 & 2.688 & 42.04 & 6.06 & 1.6 \\
\hline 5 & 153 & 13 & 1.153 & 45.45 & 6.04 & 1 \\
\hline 6 & 1 & 1 & 0 & 95.61 & 10.67 & 7.6 \\
\hline 7 & 1213 & 25 & 2.557 & 11.65 & 2.90 & 8.5 \\
\hline 8 & 3 & 1 & 0 & 97.49 & 10.82 & 6.7 \\
\hline 9 & 679 & 25 & 3.129 & 15.87 & 1.88 & 7.8 \\
\hline 10 & 599 & 26 & 2.742 & 23.58 & 2.86 & 9 \\
\hline
\end{tabular}

Table 3

Pearson's correlation among biotic and abiotic variables $(* * * \mathrm{p}<0.001 ; * * \mathrm{p}<0.02 ; * \mathrm{p}<0.05$; NS $=$ non significant $)$

\begin{tabular}{|c|c|c|c|c|c|c|}
\hline & Abundance & Species No & Diversity & $\%$ mud & Org. Matter & Depth \\
\hline Absolute abundance & 1.000 & & & & & \\
\hline Species number & $* * * 0.726$ & 1.000 & & & & \\
\hline Diversity & $* * * 0.580$ & $* * * 0.918$ & 1.000 & & & \\
\hline$\%$ mud & $* * *-0.612$ & $* * *-0.808$ & $* * *-0.855$ & 1.000 & & \\
\hline Organic matter & $* * *-0.674$ & $* * *-0.838$ & $* * *-0.850$ & $* * * 0.968$ & 1.000 & \\
\hline Depth & $* * * 0.505$ & $* * 0.426$ & $* 0.181$ & NS - 0.0998 & $*_{-}-0.215$ & 1.000 \\
\hline
\end{tabular}

variables explaining the faunal distribution, while depth appears to be the less important factor affecting worm distribution. According to sediment enrichment, three clear groups of species and stations can be distinguished in the graph: (1) stations characterised by high amounts of organic matter and mud, which are located close to the fish processing factory, the slaughterhouse and the domestic sewage, where no fauna was found; (2) stations located close to the shrimp farm, with lower organic matter content and mud, in which Streblospio benedicti and oligochaetes dominate; (3) stations close to the input coming from thermoelectric plant with lower sediment enrichment and dominated by C. capitata and Mediomastus californiensis.

\section{Discussion}

The 63 polychaete species identified here were previously reported in the Gulf of California or in California, USA, in shallow and slope depths, in soft bottoms or mixed sediments (Hartman, 1968, 1969; Kudenov, 1980; Hernández-Alcántara, 1992). Except for Caulleriella alata, Neanthes succinea and Diopatra splendidissima, which were reported by Alvarez-León (1980), the remaining 60 species are reported for the first time in soft bottoms of the
Urías estuary. The specific differences between February and April samples (i.e. Cossura pygodactylata, Prionospio cirrifera, C. alata, Caulleriella bioculata and Armandia brevis) can be attributable to the typical patchy distribution of annelids inhabiting soft bottoms.

It has been demonstrated that the organic matter content in non-degraded zones fluctuates between 0.5 and $5 \%$, while sediments containing more than $15 \%$ of organic matter can be considered typical from polluted areas (De la Lanza, 1986; López-Jamar, 1981). Faunistic analyses have shown that low values of specific diversity are typical of unstable sandy and muddy bottoms. Thus, systems subjected to organic pollution are characterised by high dominance of few species (Gray and Mirza, 1979). According to Mackie et al. (1997), the recognition of biological 'communities' or assemblages is highly dependent on the scale of sampling and the analytical methodology employed. The classification and ordination techniques used here were useful to perform a characterisation of the system based on the annelid distribution according to environmental variables. Thus, three zones were identified in the Urías estuary.

(1) 'Unpolluted zones', characterised by the presence of low organic matter content in sediment, high diversity and no dominance of any of the species. They are located in two areas: station 4 which is surrounded by mangrove trees and 


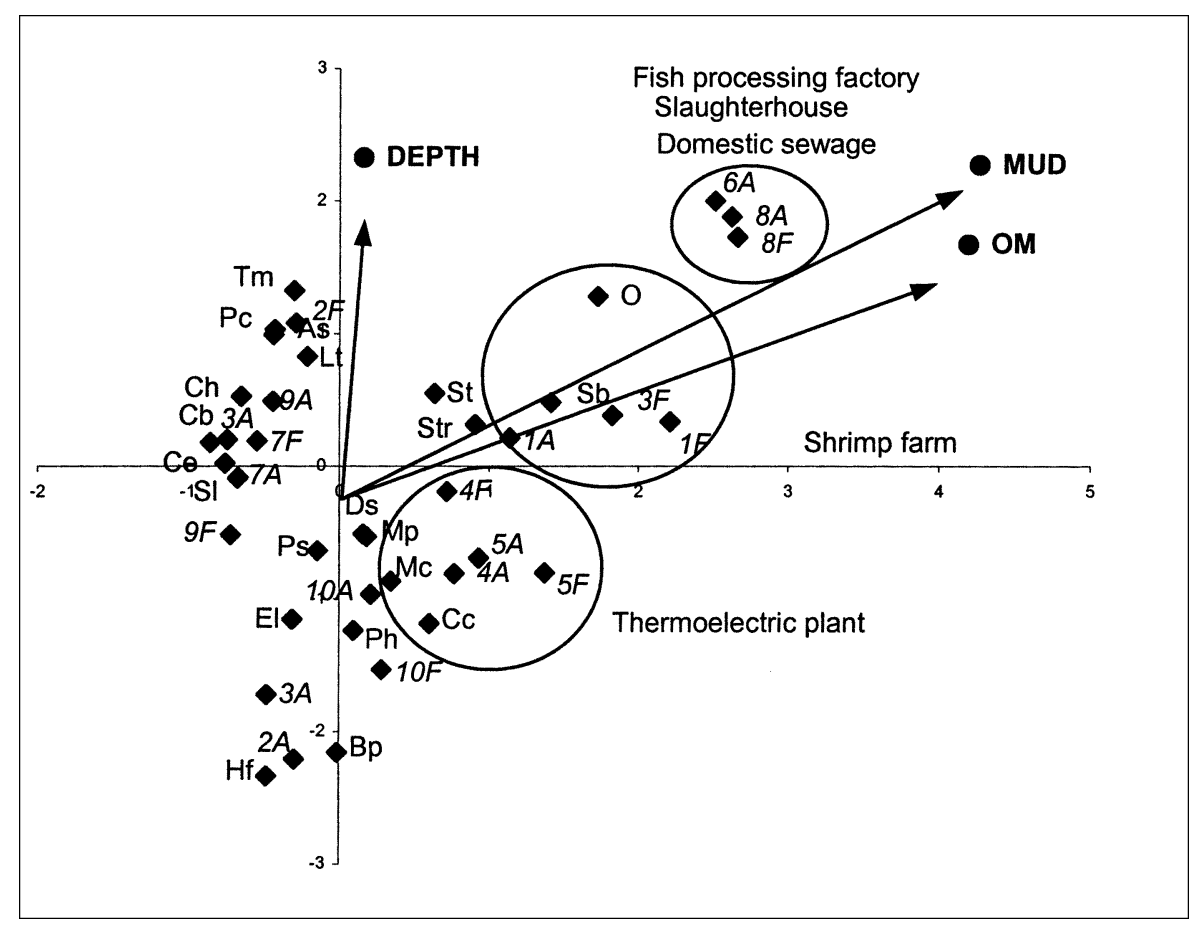

Fig. 3. Canonical correspondence analysis ordination showing the 22 dominant and frequent species and the stations with respect to the abiotic variables, relative to axes I and II (As, Aricidea suecica; Ab, Armandia brevis; Bp, Brada pluribranchiata; Cc, Capitella capitata; Cb, Caulleriella bioculata; Ch, Caulleriella hamata; Ce, Chone ecaudata; Ds, Diopatra splendidissima; El, Exogone lourei; Hf, Heteromastus filiformis; Lt, Lumbrineris tetraura; Mc, Mediomastus californiensis; Mp, Megalomma pigmentum; O, Oligochaeta; Ps, Polydora socialis; Pc, Prionospio cirrifera; Ph, Prionospio heterobranchia newportensis; S1, Schistomeringos longicornis; Str, Scolelepis tridentata; St, Sigambra tentaculata; Sb, Streblospio benedicti; Tm, Tharyx monilaris; 1F-10F, stations during February; 1A-10A, stations during April).

close to the mouth of the estuary (stations $7,9,10$ ) in which typical estuarine and marine species are mixed.

(2) 'Polluted zones' characterised by the dominance of a few species, especially from the polychaete families Capitellidae and Spionidae, as well as oligochaetes. Organic matter in these zones ranges from 3.66 to $10.95 \%$. These zones are comparable with the 'polluted bottoms' (Reish, 1959) and the 'Polluted zone' (Bellan, 1967a, b). These zones are located in several areas from the Urías estuary: in front of the domestic sewage coming through the 'Infiernillo' stream (station 8) which is characterised by the sporadic presence of oligochaetes; the thermoelectric plant (station 5), in which dominated the capitellid C. capitata; the 'Clementina' shrimp farm (station 1), dominated by the spionid S. benedicti and oligochaetes. This station receives effluents of a semi-intensive shrimp farm which could also be the responsible of the dominance of $S$. benedicti, since this species has been reported to live in salinities ranging from 28 to 35 (Levin and Huggett, 1990). The farm effluents produced a gradient towards the body of the estuary in which these species were substituted by the capitellids M. californiensis and C. capitata as dominant species.

(3) 'Very polluted zone'. It is located in front of the slaughterhouse and the fish processing factory (station 6) which organic wastes are deposited directly into the estuary producing a strong sediment enrichment (11.5 and 10.7\% organic matter) and thus the total lack of macrofauna. This zone could be equivalent to the 'very polluted bottoms' proposed by Reish (1959) or the 'maximal pollution zones' from Bellan (1967a, b), which have been characterised by the absence of macrofauna.

The species substitution observed close to the shrimp farm has also been described by Tsutsumi (1990) and Inglis and Kross (2000) in disturbed environments. Levin and Huggett (1990) have indicated that the planktotrophic development-mode of $S$. benedicti is more common in disturbed sediments. This species has been found as a pollution indicator of enriched sediments, being codominant with $C$. capitata and also has been reported as a pioneer species following abatement (Pearson and Rosenberg, 1978), which suggests that organic enrichment in the surrounding area of the shrimp farm do not reach the maximal degree as has been confirmed by the not extremely high organic matter content in sediment $(9.47 \%$ in February and $5.13 \%$ in April).

The presence of large amounts of specimens belonging to Spionidae, as well as the more or less constant presence of capitellids suggest that the 'polluted zones' identified in the Urías estuary are, in some degree, affected by domestic and industrial activities. Nevertheless, the sporadic presence of C. capitata suggests that pollution is not severe enough to consider this relatively small area $\left(18 \mathrm{~km}^{2}\right)$ as extremely enriched, as other larger polluted areas around the world like Los Angeles (Reish, 1959), Marseille (Bellan, 1967a, 
b), Loch Eil and Loch Linnhe (Pearson and Rosenberg, 1978) or Barcelona (Méndez et al., 1998).

Results presented here are almost consistent with data reported previously in the same estuarine system. OchoaIzaguirre et al. (2002) characterised the zone according to the macroalgal assemblages and found four different biotic zones: the mouth of the estuary with a transition between the marine and estuarine environments, next to the Infiernillo with the influence of urban waste waters, the zone influenced by the thermoelectric plant with an increase of water temperature, and the area covered by mangrove and close to the shrimp farm. Also, Alvarez-León (1980) characterised the area according to morphology, sediments, coastal vegetation, benthic flora and fauna, depth, and type of effluents dumped in the estuary and suggested three zones: the mangrove zone and the shrimp farm, the industrial zone, from the thermoelectric plant to the fish industry, and the zone comprised from the harbour to the mouth of the estuary. In general terms, the characterisations from such authors are similar to that reported in this study; nevertheless, the 'very polluted zone' in front of the slaughterhouse and the fish processing factory found here was not reported by them. The ordination analyses performed by Ochoa-Izaguirre et al. (2002) did not include the stations close to this area inside any of the assemblage groups probably due to the presence of a unique macroalgal species, Enteromorpha clathrata, which is typical from sediments containing high contents of organic matter. On the other hand, Alvarez-León (1980) only reported the presence of anoxic mud but did not take biological samples in this area.

\section{Conclusions}

This study has contributed to increase the list of polychaetes inhabiting soft bottoms in the Urías estuary, which was poorly studied. The annelid fauna has been demonstrated to be an important tool to characterise the system according to variations in granulometry and organic matter content in sediment subjected to the effect of human impact. Due to the location of the different anthropogenic activities developed in the estuary, a patchy distribution pattern of annelids was observed. Pollution seems to be not severe enough in the vicinities of the shrimp farm, the thermoelectric plant and the domestic sewage input; nevertheless, a very polluted zone was observed in front of the fish processing factory and the slaughterhouse which causes the total lack of macrofauna. Unpolluted zones were found in the area subjected to the marine influence and a small area surrounded by mangroves in the inland area of the estuary that has high biodiversity. This preliminary characterisation of the Urías estuary during the drought season has indicated the need for more continuity in order to better evaluate the health condition of the system as a whole.

\section{Acknowledgements}

This study was supported by the Instituto de Ciencias del Mar y Limnología, Unam, Unidad Académica Mazatlán. I am grateful to José Salgado, Arturo Núñez, Efraín Barranco and Marcelo García for their help during sampling. Thanks are also given to German Ramírez, José Salgado and José Luis Carballo for their assistance in data processing by computing programmes.

\section{References}

Alvarez-León, R., 1980. Necton y bentos de tres esteros adyacentes a Mazatlán (Sin.) México. Rev. Biol. Trop 28, 237-262.

Bellan, G., 1967a. Pollution et peuplements benthiques sur substrat meuble dans la région de Marseille. Première partie. Le secteur de Cortiou. Rev. Int. Océanogr. Méd VI-VII, 53-87.

Bellan, G., 1967b. Pollution et peuplements benthiques sur substrat meuble dans la région de Marseille. Deuxième partie. L'ensemble portuaire marseillais. Rev. Int. Océanogr. Méd VIII, 51-95.

Bellan, G., 1984. Indicateurs et indices biologiques dans le domaine marin. Bull. Ecol. 15, 13-20.

Borja, A., Franco, J., Pérez, V., 2000. A marine biotic Index to establish the ecological quality of soft-bottom benthos within European estuarine and coastal environments. Mar. Poll. Bull. 40, 1100-1114.

Dean Jr, W.E., 1974. Determination of carbonate and organic matter in calcareous sediments and sedimentary rocks by loss of ignition: comparison with other methods. J. Sed. Petrol. 44, 242-248.

De La Lanza, G., 1986. Materia orgánica de los sedimentos del sistema lagunar Huitzache y Caimanero: importancia, comportamiento y significado en modelos de predicción. An. Inst. Cienc. Mar. Limnol. Univ. Nal. Autón. México 13, 251-286.

Fauchald, K., 1977. The Polychaete worms. Definitions and Keys to the Orders, Families and Genera. Nat. Hist. Mus. Los Angeles County, Sci. Ser 28, 1-188.

Glémarec, M., 1964. Bionomie benthique de la partie orientale du golfe du Morbihan. Cah. Biol. Mar. 5, 33-96.

Glémarec, M., Hily, C., 1981. Perturbations apportées à la macrofaune benthique de la baie de Concarneau par les effluents urbains et portuaires. Acta Oecol. Applic 2, 139-150.

Grassle, J.F., Grassle, J.P., 1974. Opportunistic life histories and genetic systems in marine polychaetes. J. Mar. Res. 32, 253-284.

Gray, J.S., Mirza, F.B., 1979. A possible method for the detection of pollution-induced disturbance on marine benthic communities. Mar. Poll. Bull. 10, 142-146.

Hartman, O., 1968. Atlas of the Errantiate Polychaetous Annelids from California. Allan Hancock Found. University of South California.

Hartman, O., 1969. Atlas of the Sedentariate Polychaetous Annelids from California. Allan Hancock Found. University of South California.

Hernández-Alcántara, P., 1992. Los poliquetos (Annelida: Polychaeta) de la plataforma continental del Golfo de California, México. Taxonomía, abundancia numérica y distribución geográfica. Tesis de Maestría. Instituto de Ciencias del Mar y Limnología, UNAM.

Hily, C., 1983. Modifications de la structure écologique d'un peuplement de Melinna palmata (Annélide Polychète) soumis aux effluents urbains et industriels en rade de Brest. Ann. Inst. Océanogr. Paris 59, 37-56.

Hily, C., Glémarec, M., 1990. Dynamique successionnelle des peuplements de fonds meubles au large de la Bretagne. Oceanol. Acta 13, 107-115.

Inglis, G.J., Kross, J.E., 2000. Evidence for systemic changes in the benthic fauna of tropical estuaries as a result of urbanization. Mar. Poll. Bull. 41, 367-376. 
Kikuchi, T., 1979. Some aspects of ecology, life cycle and taxonomy of the polychaete Capitella capitata, so-called pollution indicator: a review. Benthos Research (Bull. Jpn. Assoc. Benthol.) 17/18, 33-51.

Kudenov, J., 1980. Annelida: polychaeta (bristleworms). In: Brusca, R.C. (Ed.), Common Intertidal Invertebrates of the Gulf of California. The University of Arizona Press, Tucson, pp. 77-123.

Levin, L.A., Huggett, D.V., 1990. Implications of alternative reproductive modes for seasonality and demography in an estuarine polychaete. Ecology 71, 2191-2208.

Levin, L., Caswell, H., Bridges, T., DiBacco, C., Cabrera, D., Plaia, G., 1996. Demographic responses of estuarine polychaetes to pollutants: life table response experiments. Ecol. Appl. 6, 1295-1313.

López-Jamar, E., 1981. Spatial distribution of the infaunal benthic communities of the Ria de Muros, North-West Spain. Mar. Biol 63, 29-37.

Mackie, A.S.Y., Parmiter, C., Tong, L.K.Y., 1997. Distribution and diversity of polychaeta in the southern Irish Sea. Bull. Mar. Sci. 60, 467-481.

Méndez, N., Flos, J., Romero, J., 1998. Littoral soft-bottom Polychaete communities in a pollution gradient in front of Barcelona (Western Mediterranean, Spain). Bull. Mar. Sci 63, 167-178.

Ochoa-Izaguirre, M.J., Carballo, J.L., Páez-Osuna, F., 2002. Qualitative changes in macroalgae assemblages under two contrasting climate conditions in a subtropical estuary. Bot. Mar. 45, 130-138.

Pearson, T.H., Rosenberg, R., 1978. Macrobenthic succession in relation to organic enrichment and pollution of the marine environment. Oceanogr. Mar. Biol. Rev 16, 229-311.
Picard, 1965. Recherches qualitatives sur les biocénoses marines des substrats meubles dragables de la region marseillaise. Rec. Trav. Stat. Mar. Endoume 36, 1-60.

Reish, D.J., 1959. An ecological study of pollution in Los Angeles, Long Beach Harbours, California. Allan Hancock Found. Publ. occ. papers 22, 1-117.

Sanders, H.L., 1968. Marine benthic diversity: a comparative study. Am. Nat. 102, 243-282.

Soto-Jiménez, M., Páez-Osuna, F., 2001. Cd, Cu, Pb, and Zn in lagoonal sediments from Mazatlán Harbor (SE Gulf of California): bioavailability and geochemical fractioning. Bull. Environ. Contam. Toxicol $66,350-356$

Tsutsumi, H., 1990. Population persistence of Capitella sp. (Polychaeta; Capitellidae) on a mud flat subject to environmental disturbance by organic enrichment. Mar. Ecol. Prog. Ser. 63, 147-156.

Tsutsumi, H., Fukunaga, S., Fujita, N., Sumida, M., 1990. Relationship between growth of Capitella sp. and organic enrichment of the sediment. Mar. Ecol. Prog. Ser. 63, 157-162.

Warwick, R.M., Pearson, T.H., Ruswahyuni, 1987. Detection of pollution effects on marine macrobenthos: further evaluation of the species abundance/biomass method. Mar. Biol. 95, 193-200.

Warwick, R.M., Clarke, K.R., 1993. Increased variability as a symptom of stress in marine communities. J. Exp. Mar. Biol. Ecol. 172, $215-226$. 